\title{
A Short-Term Sublethal In Situ Sediment Assay with Chironomus riparius Based on Postexposure Feeding
}

\author{
S. Soares, ${ }^{1}$ I. Cativa, ${ }^{1}$ M. Moreira-Santos, ${ }^{1}$ A. M. V. M. Soares,${ }^{2}$ R. Ribeiro ${ }^{1}$ \\ ${ }^{1}$ Instituto do Ambiente e Vida, Departamento da Zoologia de Universidade de Coimbra, Largo Marquês de Pombal, $3004-517$ Coimbra, Portugal \\ ${ }^{2}$ Departamento da Biologia de Universidade de Aveiro, Campus Universitário de Santiago, 3810-193 Aveiro, Portugal
}

Received: 18 March 2004/Accepted: 18 January 2005

\begin{abstract}
A short-term, sublethal, and cost-effective in situ sediment toxicity assay for routine assessments with the midge Chironomus riparius Meigen, based on postexposure feeding, was developed and evaluated. An inexpensive and easy-to-use assay chamber was designed. A sediment toxicity assay was successfully performed at a lentic system impacted by acid mine drainage, at sites with different types of sediment. It consisted of a 48-h exposure period followed by a 1-h postexposure feeding during which the larvae were fed on Artemia franciscana nauplii. Methodologies for feeding quantification of fourth-instar larvae (10-d old) were first developed and optimized under laboratory conditions. A. franciscana nauplii were shown to be more suited than fish flake food for postexposure feeding quantification, allowing higher precision and cost-effectiveness. It also required a shorter postexposure feeding period, thus minimizing the chances for an eventual organism physiological recovery from toxicant exposure. The influence of several environmental conditions during exposure on postexposure feeding was also evaluated: temperature, dissolved oxygen, $\mathrm{pH}$, salinity, hardness, substrate, humic acids, light, and food availability. Only temperature was found to significantly influence postexposure feeding rates; exposure at $5^{\circ} \mathrm{C}$ led to reduced feeding activity compared to $30^{\circ} \mathrm{C}$. Recovery rates of $87 \%$ were obtained after the 48 -h field exposure at all sites (except site R2). A statistically significant postexposure feeding depression was observed at the three sites impacted by acid mine drainage. Therefore, the proposed short-term in situ assay is a potentially useful tool to assess sediment sublethal toxicity on a routine basis.
\end{abstract}

The use of in situ, instead of laboratory, bioassays reduces artifacts related with sample collection, handling, and storage, which are particularly relevant in sediment toxicity testing (Tucker and Burton 1999; Castro et al. 2003). The assessment of the impact of pollutants in situ has generally been based on

Correspondence to: R. Ribeiro; email: rui.ribeiro@zoo.uc.pt the examination of lethal effects (Ireland et al. 1996; Chappie and Burton 1997; Pereira et al. 1999). Although several sublethal in situ bioassays have been developed, these are mainly long-term assays based on growth or reproduction as toxicity endpoints (Pereira et al. 2000; Ringwood and Keppler 2002; Castro et al. 2003). However, long-term in situ exposures present some drawbacks such as the rise of study costs and of effects associated with potential confounding factors (e.g., organism caging and toxicant exposure regime), which complicate the establishment of a causal link between toxicant exposure and the observed biological response (Chappie and Burton 2000; Castro et al. 2003). Simple, rapid, and inexpensive in situ toxicity assays would be very useful in aquatic ecotoxicology by allowing assessments to be conducted on a routine basis with a variety of species (Cairns and Cherry 1993).

The use of feeding depression as a sublethal assay endpoint has already been investigated in the laboratory for various groups of organisms including ciliates (Juchelka and Snell 1995), rotifers (Juchelka and Snell 1994), cladocerans (Juchelka and Snell 1995; McWilliam and Baird 2002a), and fish (Little and DeLonay 1996). Also with in situ assays, toxicantinduced feeding depression has been increasingly used as a sublethal as well as short-term endpoint (e.g., amphipods [Maltby et al. 2002], cladocerans [McWilliam and Baird 2002b], and small fish [Castro et al. 2004]). Alterations in feeding behavior are known to influence the organism's physiological performance, interfering with specific life-history events such as development, growth, and reproduction, and eventually causing changes at higher levels of biological organization (Maltby 1994; Begon et al. 1996; Sibley et al. 1997). Thus, a depression in feeding has been used as a rapid response to a toxic stress as well as a first indication for other physiological responses likely to appear later, at the population level and community level (Maltby 1994; Little and DeLonay 1996; Maltby et al. 2002). For in situ toxicity assessments, the use of a postexposure period to quantify feeding avoids the difficulties inherent to the quantification of feeding during the field exposure. Obviously, the selection of such an assay endpoint for an in situ assay requires that both organism physiological recovery from toxic effects and organism stress due to handling should be minimal. 


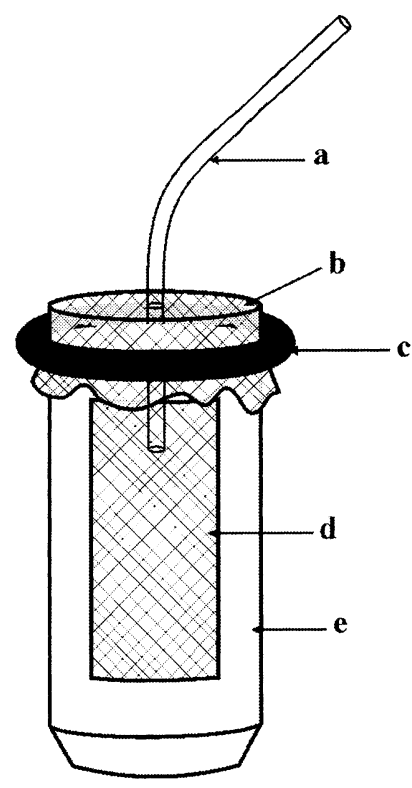

Fig. 1. Assay chamber designed for the 48-h in situ assay with Chironomus riparius larvae (not drawn to scale). (a) 2-m-long and 4$\mathrm{mm}$-id transparent plastic tube. (b) $15-\mathrm{cm}^{2}$ cover of $200-\mu \mathrm{m}$ nylon mesh. (c) 1 -cm-wide elastic band. (d) $4 \times 10-\mathrm{cm}$ lateral windows covered with a $200-\mu \mathrm{m}$ nylon mesh. (e) 20 -cm-long and 5-cm-id acrylic tube.

Chironomus riparius is among the group of species most frequently used in sediment ecotoxicological testing, both in the laboratory and in situ (Ingersoll et al. 1995; OECD 2001; ASTM 2002a; Castro et al. 2003). It belongs to the most widely distributed and frequently most abundant group of insects in freshwater environments (Pinder 1986). The tubicolous larvae have direct contact with the sediment by burrowing to build a case, and extend their anterior ends outside the tubes to feed on sediment surface detritus (ASTM 2002a). Chironomids often inhabit eutrophic lakes, ponds, streams, and littoral muddy shallow habitats, and are important in the diet of fish and birds. They are important in the recycling of organic matter and energy, and link aquatic and terrestrial environments, because they need both to complete their life cycle (Gerhardt 1993). In addition to the functionally important niche occupied by the species, other characteristics led to its ecotoxicological suitability, such as the existence of an established method for easy laboratory culturing (OECD 2001) and the knowledge about its sensitivity to many contaminants (Timmermans et al. 1992; Postma et al. 1995; Stuijfzand et al. 1998).

The main aim of the present study was to develop and evaluate a short-term, sublethal, and cost-effective in situ sediment toxicity assay for routine assessments with C. riparius larvae, based on postexposure feeding. Four specific objectives were outlined: (1) to develop a simple methodology to precisely quantify $C$. riparius larvae feeding rate in a short period, in order to reduce the chances of an eventual physiological recovery after toxicant exposure; (2) to develop simple and inexpensive assay chambers and procedures for both lentic and lotic systems and for a wide range of sediment structure characteristics (particle size and water content); (3) to investigate the influence of various environmental exposure conditions on postexposure feeding, in order to be able to distinguish environmental from pollutant effects; and (4) to evaluate this short-term sublethal in situ sediment assay at a well studied impacted area.

\section{Materials and Methods}

\section{Assay Organism and Culture Conditions}

All experiments were conducted with fourth-instar larvae (10-d old) of C. riparius Meigen. For larval instar selection, both the ease of feeding quantification and the manipulations involved with in situ deployment and retrieval were considered. Even though it has been shown that older instars of Chironomus sp. larvae are more resistant to toxicants, such instars also produce more precise responses because of their lower natural mortality and susceptibility to handling compared to younger instars (Larrain et al. 1997; USEPA 2000).

Midge larvae were obtained from a laboratory culture maintained at $20 \pm 1{ }^{\circ} \mathrm{C}$ under a 14:10-h L:D cycle with a 90-min period of dawn and dusk, inside a $40 \times 60 \times 120$-cm closed transparent acrylic box, following procedures described by Castro et al. (2003). Briefly, substrate was quartz seasand (0.1- to 0.4-mm particle size) (Merck, 7712, Darmstadt, Germany). Culture water was the ASTM reconstituted hard water (280-320 mg $\mathrm{CaCO}_{3} \mathrm{mg} / \mathrm{L}$; [ASTM 2002b]). First instar larvae (newly hatched) were reared in crystallizing dishes at a density of 30 larvae per $150 \mathrm{~g}$ of substrate and $300 \mathrm{ml}$ of water until day 7. Sets of 15 larvae were then transferred to newly prepared dishes until emergence. Crystallizing dishes were placed inside the culture box and were provided with gentle aeration. Larvae were fed with fish flake food (Tetramin) (TetraWerk, Melle, Germany), ground to small particles and suspended in culture water $(1 \mathrm{~g}$ in $20 \mathrm{ml})$ before being added at a rate of $0.1 \mathrm{~g}$ dry Tetramin/crystallizing dish, every $2 \mathrm{~d}$. On emergence (after four larval instars and a pupa stage), adults fed on a sucrose solution wetted paper. After mating, females laid gelatinous egg masses on crystallizing dishes containing culture water. The egg masses were then transferred to 5-cm diameter plastic dishes filled with the same water.

\section{Assay Chamber and Procedures}

In situ chambers were constructed specifically for short-term field exposures of $C$. riparius larvae (Figure 1). The assay chamber consisted of a $20-\mathrm{cm}-$ long and 5-cm-id acrylic tube. Two $4 \times 10-\mathrm{cm}$ rectangular windows were opened laterally in the tube and covered with a $200-\mu \mathrm{m}$ nylon mesh using white thermal glue (Elis-Taiwan, TN122/WS, Taiwan; chemical composition: 50\% ethylene-vinylacetate copolymer, $45 \%$ synthetic hydrocarbon, and $5 \%$ polyethylene wax), which has been shown to be nontoxic to cladocerans (Pereira et al. 1999). A $15 \times 15-\mathrm{cm}^{2}$ of a $200-\mu$ m nylon mesh, held by a $1-\mathrm{cm}-$ wide elastic band, was used to cover the top of the assay chamber. A 2-m-long transparent plastic tube (4-mm-id) was inserted and glued at the center of the top mesh cover, to allow the introduction of test organisms with no sediment disturbance. Before testing, all assay chambers were submersed in deionized water for $24 \mathrm{~h}$. A holding structure constructed from a $10 \times 21 \times 25$-cm basket made of plasticcoated metal wire was used to ensure the maintenance of each assay chamber position in lentic as well as lotic systems (Figure 2). A central $6 \times 7-\mathrm{cm}$ rectangular opening was made to allow positioning of the assay chamber. For deployment, assay chambers were pushed about $10 \mathrm{~cm}$ into the sediment. The lateral windows allowed both the flow of the overlying water at the water-column level and of 


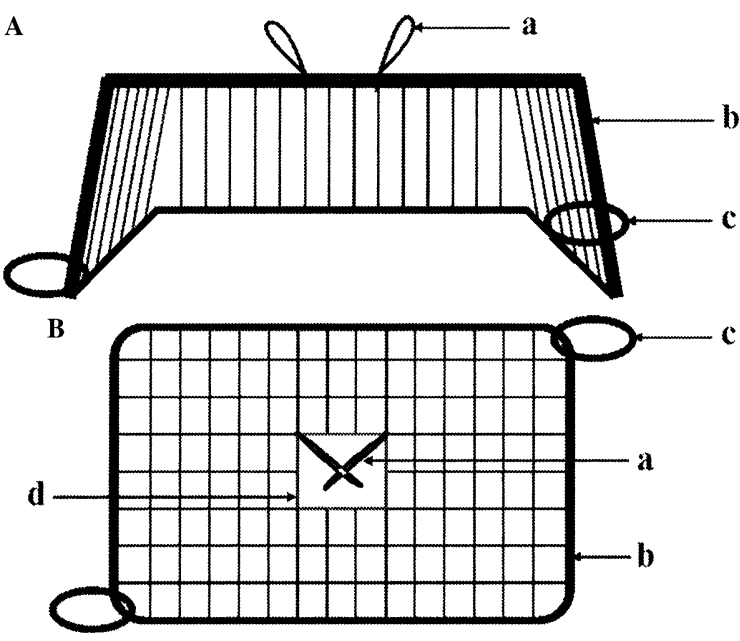

Fig. 2. Holding structure designed for the 48-h in situ assay with Chironomus riparius larvae (not drawn to scale). (A) Side view. (B) Top view. (a) 1 -cm-wide elastic bands. (b) $10 \times 21 \times 25$-cm plasticcoated metal wire basket. (c) 5 -cm-diameter plastic rings. (d) $6 \times 7-\mathrm{cm}$ opening to position the assay chamber.

porewater at the sediment level. Each holding structure was then deployed and attached to the respective assay chamber through two elastic bands (Figure 2). The holding structure was staked to the sediment with the help of two wooden sticks each passing through a 5$\mathrm{cm}$ diameter plastic ring (Figure 2). Additional staking may be required at lotic systems. Four metal sticks were used to deploy each holding structure in a river with a $0.75 \mathrm{~m} / \mathrm{s}$ current (Bestança River within the Douro River Basin, Northern Portugal). This procedure allowed the assay chambers to be successfully deployed for a 48-h period.

A leveling structure was also designed to be used in soft sediments to avoid the holding structures and chambers from sinking into the sediment. It was constructed from a $33 \times 44-\mathrm{cm}$ plastic tray in which a central $8 \times 10-\mathrm{cm}$ rectangular opening (for the assay chamber) and two 8-mm-diameter holes were made on opposite sides. Each holding structure was attached to a leveling structure with two plastic bands passing through the small holes.

Assay chambers were deployed $3 \mathrm{~d}$ before testing to allow the establishment of an equilibrium between the sediment porewater inside and outside the assay chambers. To begin the assay, five fourthinstar larvae were inserted into each assay chamber through the 2-mlong transparent plastic tube (to avoid sediment disturbance), with the help of a syringe. Assay chambers were retrieved $48 \mathrm{~h}$ later and transported with the sediment to the laboratory. To avoid sediment losses during transport, the bottom end of each chamber was closed, first by hand and, after complete retrieval, with a tight-fitting cork. Each chamber was placed inside a black plastic bag and transported to the laboratory inside thermally insulated boxes, at $20 \pm 2^{\circ} \mathrm{C}$. Upon arrival to the laboratory (3-4 h later), larvae were carefully collected from the sediment to immediately start postexposure feeding rate determinations following procedures described below.

\section{Feeding Quantification}

To develop the methodologies to quantify feeding rates, two types of food were evaluated in separate experiments: fish flake food (Tetramin) and Artemia franciscana Kellog nauplii. For the experiment on the use of Tetramin, groups of six larvae were transferred to 40-ml glass vials containing $30 \mathrm{ml}$ of ASTM hard water. Sieved Tetramin
(100-200 $\mu \mathrm{m})$ was added at a concentration of $1.5 \mathrm{mg}$ dry weight/ larva ( $9 \mathrm{mg} / \mathrm{vial})$. Two additional controls were also set up: one with ASTM hard water and food, but without larvae, to estimate eventual errors associated with the Tetramin quantification process, and another with ASTM hard water and larvae, but without food, to estimate the amount of the final particle weight due to feces. For each treatment, three replicates were set up. Feeding was allowed for $24 \mathrm{~h}$, at $20 \pm 1{ }^{\circ} \mathrm{C}$, in the dark, and with gentle aeration. After $24 \mathrm{~h}$, larvae were removed and the content of each vial was vacuum filtered through a previously weighted $10-\mu \mathrm{m}$ nylon mesh filter $\left(1 \mathrm{~cm}^{2}\right)$. All filters were dried at $60^{\circ} \mathrm{C}$ for $24 \mathrm{~h}$ and final Tetramin dry weight in each filter was determined to the nearest $0.1 \mathrm{mg}$ using a semimicrobalance (Sartorius Research R200D, Bradford, Germany). Feeding rates ( $\mathrm{mg}$ dry weight Tetramin/larva/h) were computed from the difference between the initial and final Tetramin dry weights, corrected for losses of food during the quantification process and presence of feces, divided by the time (h) they were allowed to feed and the total number of larvae in each vial.

To evaluate the use of A. franciscana as food, newly hatched nauplii $(<24$-h old) were obtained by incubating cysts (Creasel, Deinze, Belgium) under continuous light, at $25 \pm 1{ }^{\circ} \mathrm{C}$, in standard reconstituted seawater (salinity $=35 \mathrm{~g} / \mathrm{L}$ and $\mathrm{pH}=7.6 \pm 0.1$ [Guillard 1983]). Hatched nauplii were counted into $1.5-\mathrm{ml}$ eppendorfs filled with ASTM hard water and frozen until use. For the feeding trial, five replicates were set up. Each replicate consisted of a 40-ml glass vial containing $30 \mathrm{ml}$ of ASTM hard water and 150 unfrozen nauplii into which five larvae were transferred. Feeding was conducted for $1 \mathrm{~h}$, at $20 \pm 1{ }^{\circ} \mathrm{C}$, in darkness. After an hour, larvae were removed and remaining nauplii were transferred to a Petri dish and counted (using a black background) under a dissecting microscope. Feeding rates (number of nauplii/larva/h) were computed from the difference between the initial and final number of nauplii divided by the total number of larvae in each vial.

Because A. franciscana nauplii were found to be a more suitable food for the feeding rate quantification of $C$. riparius larvae than Tetramin, it was selected to be used in the in situ sediment assay proposed here. To optimize the feeding rate of $C$. riparius larvae on A. franciscana nauplii, the influences of light conditions and larval density during the 1-h feeding period were investigated separately. Both experiments were performed following the same conditions described above, except for the experimental variable. Two light conditions were investigated: no light and $250 \mathrm{~lx}$-continuous coolwhite fluorescent light. Five larval density treatments were set up: one, two, three, four, and five larvae per vial. In the no-light and in the one- and 5-larvae treatments, a replicate was lost.

\section{Influence of Exposure Conditions on Postexposure Feeding}

The influence of the following environmental conditions during the 48-h exposure period on postexposure feeding rates was investigated in the laboratory: temperature, dissolved oxygen (DO), $\mathrm{pH}$, salinity, hardness, substrate, humic acids, light, and food availability. Except when stated otherwise, larvae were exposed during $48 \mathrm{~h}$, at $20 \pm 1^{\circ} \mathrm{C}$, under a 14:10-h L:D photoperiod, with gentle aeration, and without food addition, in 175-ml glass vials (5-cm-id) containing $100 \mathrm{ml}$ of ASTM hard water and a 1.5-cm-high layer of standard seasand. Three replicates, with five larvae each, were used per treatment. Overlying water temperature, DO (WTW OXI 92, Weilheim, Germany), and pH (WTW 537) were measured at the beginning (before larvae introduction) and end (after larvae retrieval) of the exposure period. DO values remained above the recommended threshold limit of 2.5 to 3.0 $\mathrm{mg} / \mathrm{L}$ (OECD 2001; ASTM 2002a), except during the DO variable experiment. Likewise, $\mathrm{pH}$ was within the recommended 6 to $9 \mathrm{pH}$ interval (OECD 2001), except during the $\mathrm{pH}$ variable experiment. At the end of the 48-h exposure period, aeration was stopped and larvae 


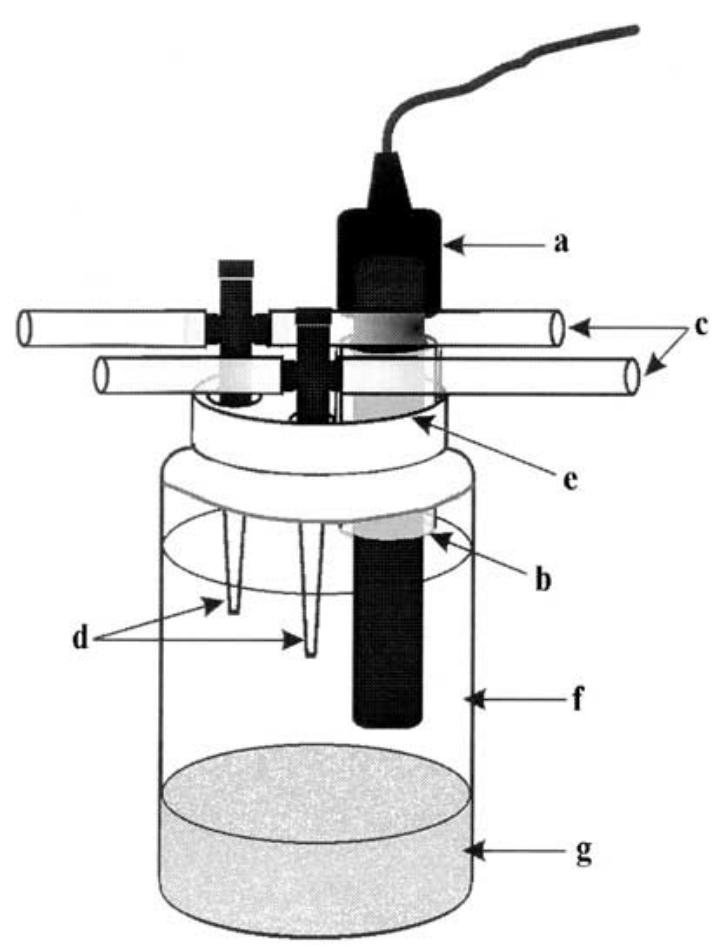

Fig. 3. Scheme of the laboratory experimental design used to determine the influence of the overlying water dissolved oxygen during the 48-h exposure period on the 1-h postexposure feeding of Chironomus riparius larvae (not drawn to scale). (a) Oxygen probe. (b) $1.8-\mathrm{cm}$ id and 4-cm-long transparent plastic tube. (c) Aeration tubes. (d) 200- $\mu 1$ Gilson pipette tips. (e) Parafilm. (f) ASTM water. (g) Sediment layer.

were maintained in the experimental vials, at $20 \pm 1{ }^{\circ} \mathrm{C}$, for an additional 4-h period, to simulate the transport of larvae from the field to the laboratory. Postexposure feeding was then immediately carried out. According to the feeding quantification section results (Results and Discussion sections), feeding was quantified in darkness, at a larval density of five larvae/vial and with 150 nauplii/vial.

Temperature treatments were performed in six controlled temperature rooms at: $5 \pm 1,10 \pm 1,15 \pm 1,20 \pm 1,25 \pm 1$, and $30 \pm 1{ }^{\circ} \mathrm{C}$. Sediment, water, and larvae were added to the $175-\mathrm{ml}$ glass vials at an ambient temperature of $20 \pm 1^{\circ} \mathrm{C}$, and only then each treatment was transferred to the respective temperature-controlled room. The influence of DO in the overlying water was investigated with exposures at 2.0, 3.0, 4.0, 5.0, 6.0, and $8.0 \mathrm{mg} / \mathrm{L}$. Dissolved oxygen concentrations were obtained by gently bubbling both air and nitrogen (Air Liquide, Algés, Portugal) $2 \mathrm{~cm}$ above the sediment surface through two $200-\mu 1$ Gilson pipette tips fixed to the respective aeration tubes (Figure 3). Test vessels were covered with Parafilm (American National Can, Chicago, Illinois) to reduce evaporation. The pipette tips and a 4-cmlong transparent plastic tube $(1.8-\mathrm{cm}$ id), for introducing the oxygen probe, were inserted in the Parafilm lid. Between DO measurements, the top of the plastic tube was also covered with Parafilm. DO concentrations were checked six times a day and adjustments to air/ nitrogen flow were made as necessary. Except for the control with DO values always equal to $8 \mathrm{mg} / \mathrm{L}$, mean ( \pm standard deviation [SD]) actual DO values differed slightly from nominal concentrations: 2.34 $( \pm 0.08), 3.27( \pm 0.06), 4.08( \pm 0.02), 5.15( \pm 0.13)$, and $6.00( \pm 0.36)$ $\mathrm{mg} / \mathrm{L}$, respectively. The $\mathrm{pH}$ treatments were $5.0,6.0,7.0,8.0$, and 9.0, obtained by adjusting the $\mathrm{pH}$ of the ASTM hard water with either $\mathrm{HCl}$ or $\mathrm{NaOH}$. Initial and final $\mathrm{pH}$ values never differed by more than 0.5 units within each treatment. Salinity levels investigated were $0.0,1.5$, 3.0, and $6.0 \mathrm{~g} / \mathrm{L}$, obtained by diluting standard seawater (Guillard
1983) with ASTM hard water. Five different hardnesses were evaluated: very soft, soft, moderately hard, hard, and very hard waters with, 10 to 13,40 to 48,80 to 100,160 to 180 , and 280 to $320 \mathrm{mg} \mathrm{CaCO}_{3} / \mathrm{L}$, respectively (USEPA 1989). To determine the influence of substrate, five different sediments and a water-only treatment were evaluated. The five sediments were: standard seasand; kaolin $(0.1-0.4-\mu \mathrm{m}$ particle size; Sigma, K-7375, Steinhein, Germany); 70\% seasand and $30 \%$ kaolin; $30 \%$ seasand and $70 \%$ kaolin; and the formulated sediment developed by Ribeiro et al. (1999): 70\% seasand, 20\% kaolin, and $10 \%$ alpha-cellulose (Sigma, C-8002, Steinhein, Germany) (all proportions were based on dry weights). The influence of humic acids (Aldrich, H1 675-2, Milwaukee, Wisconsin) was investigated using five different concentrations: $0.0,0.5,1.0,1.5$, and $2.0 \mathrm{mg} / \mathrm{g}$ of humic acids. For each replicate, the humic acids were first mixed with the seasand and with about $20 \mathrm{ml}$ of the 100-ml ASTM hard water. Then, the remaining water was added and the mixture was left to stabilize for $24 \mathrm{~h}$. The influence of light was assessed through two treatments: exposure in the dark and under a 14:10-h L:D photoperiod. To assess the influence of food availability, larvae were exposed under two treatments: no feeding and $3.6 \mathrm{mg}$ dry weight of grounded Tetramin per larva during the 48-h exposure, supplied at the start of the experiment.

\section{In Situ Toxicity Assay}

To evaluate the suitability of this in situ assay based on postexposure feeding to detect field toxicity, an assay was performed at the abandoned S. Domingos cupric-pyrite mining area (within the Guadiana River Basin, SE Portugal). This is a well-described system where extensive ecotoxicological research has already been carried out (Pereira et al. 1995; Lopes et al. 1999a,b; Pereira et al. 1999, 2000; Castro et al. 2003; Castro et al. 2004; Moreira-Santos et al. 2004). It is a system historically impacted by acid mine drainage resulting from the ongoing oxidation of mine tailings, and where no other significant contaminant sources are present (Castro et al. 2003). This mine drainage is characterized by very low $\mathrm{pH}(\leq 3.0)$ and high heavy metal concentrations (mainly $\mathrm{Fe}, \mathrm{Al}, \mathrm{Zn}, \mathrm{Cu}, \mathrm{Cd}, \mathrm{Cr}, \mathrm{Pb}$, and $\mathrm{As}$ [Pereira et al. 1995; Lopes et al. 1999a; Pereira et al. 2000; MoreiraSantos et al. 2004]). Mine effluent is slightly diluted by the Mosteirão Stream and discharged into the Chança River Reservoir (Figure 4). Three impacted sites (I1, I2, and I3) along the Mosteirão Stream, downstream from the point of effluent discharge, and two references, R1 on the Mosteirão Stream upstream of the effluent discharge and R2 in the Chança Reservoir, were selected (Figure 4). The two reference sites were selected in distinct parts of the system to enable calculation of postexposure feeding over a range of chemical and physical parameters characterizing the uncontaminated part of the system. Site I3 was not part of the main effluent course but was, instead, a puddle originated by the lowering of the water-column level due to an intense evaporation. Three replicate assay chambers were deployed at each site as described above. After a 48-h exposure period, assay chambers were retrieved and transported to the laboratory. Postexposure feeding rate quantifications were performed immediately upon arrival at the laboratory, following the procedures described in the previous section.

Water-column temperature, conductivity (WTW LF 92), and pH were recorded at the beginning and at the end of the in situ assay. At the end of the assay and prior to chamber retrieval, sediment samples were taken just beside the assay chambers. A tube equivalent to an assay chamber (20-cm long) was used for sampling sediment at the same depth reached by assay chambers. Three replicate samples from each site were composited, sealed in airtight plastic bags, transported to the laboratory, and stored in the dark at $4{ }^{\circ} \mathrm{C}$ until processed for analysis (USEPA 2000; ASTM 2002a). Composite sediment samples were used for water content, organic matter content (percent volatile solids), and particle size distribution analysis. Water content was 


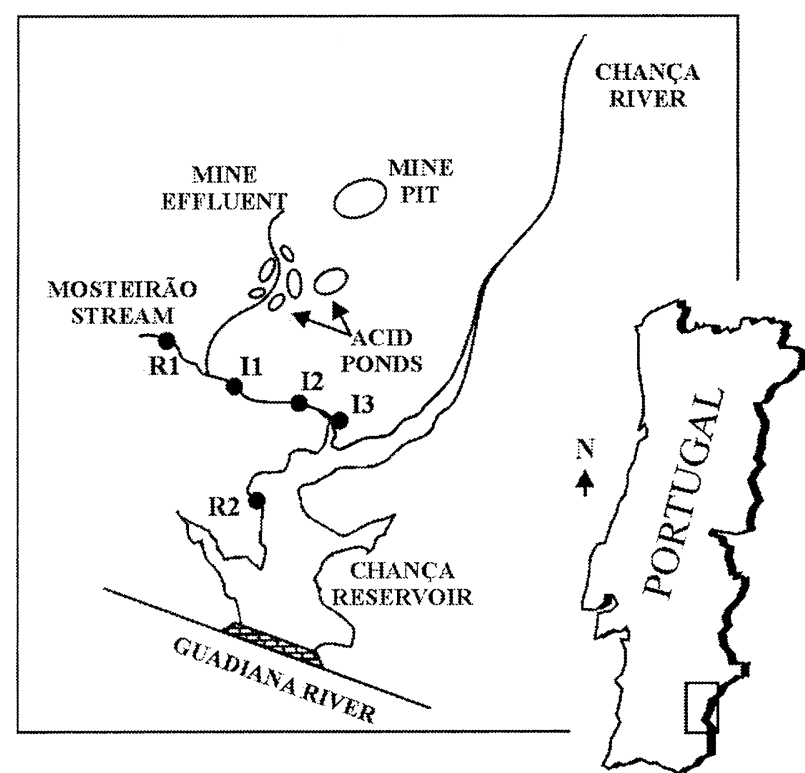

Fig. 4. The aquatic system of S. Domingos mine with location of two reference (R1 and R2) and three impacted sites (I1, I2, and I3).
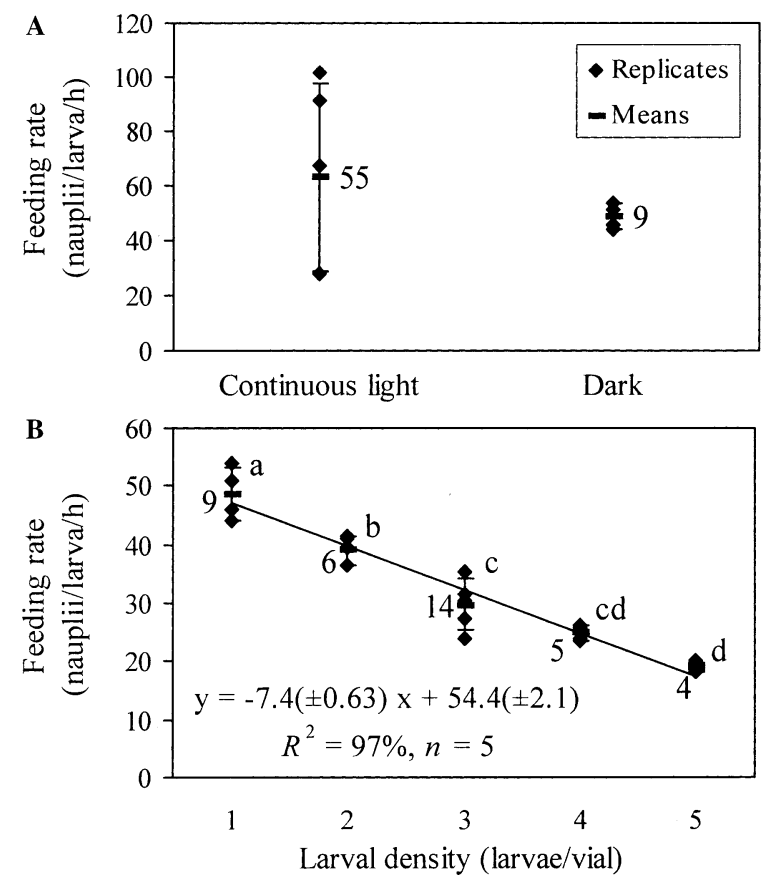

Fig. 5. Feeding rates of Chironomus riparius larvae fed for $1 \mathrm{~h}$ on A. franciscana nauplii under two light conditions (A) and at different larval densities (B). Error bars indicate $\pm 1 \mathrm{SD}$; numbers beside means are $\mathrm{CVs}(\%)$; common letters beside means identify homogeneous groups by Tukey HSD test.

determined by measuring the loss of sediment weight after ovendrying at $100^{\circ} \mathrm{C}$ for $24 \mathrm{~h}$, and was expressed as the percentage of the initial wet weight of the sediment (Buchanan and Kain 1971). Organic matter content was determined by quantifying the loss of weight after ignition at $500^{\circ} \mathrm{C}$ for $24 \mathrm{~h}$, and was expressed as the percentage of the oven-dry weight of the sediment (Buchanan and Kain 1971). The sediment particle size distribution was analyzed by sieving it into three fractions: silt and clay $(<0.062 \mathrm{~mm})$, sand $(0.062-2.0 \mathrm{~mm})$, and gravel $(>2.0 \mathrm{~mm})$, and was then classified according to the Wentworth scale (Buchanan and Kain 1971). Porewater was extracted by squeezing each composite sediment sample against a $10-\mu \mathrm{m}$ Teflon mesh using pure nitrogen at $2 \mathrm{~atm}$ and a device similar to the one developed by Carr et al. (1989). Porewater was analyzed for conductivity and $\mathrm{pH}$ and then preserved by acidification to $\mathrm{pH} 2$ with $\mathrm{H}_{2} \mathrm{NO}_{3}$, and stored at $4^{\circ} \mathrm{C}$ for metal analysis (APHA 1995). Total aluminum, zinc, cobalt, manganese, cadmium, copper, iron, selenium, and lead were the metals analyzed. Total metals include those inorganically and organically bound, both dissolved and particulate, and were quantified (by a certificated laboratory: EgiAmbiente, Vila Nova de Gaia, Portugal), after vigorous digestion on unfiltered samples, using ICP spectrophotometry (APHA 1995).

\section{Data Analysis}

Larval feeding rates were analyzed for significant differences through $t$ tests or one-way analyses of variance (ANOVAs) followed by multiple comparison Tukey HSD tests (Zar 1996), using the software STATISTICA 5.0 (StatSoft, Tulsa, Oklahoma). The assumptions of normality and homoscedasticity were verified using the KolmogorovSmirnov test and the two-tailed variance ratio test $(\mathrm{k}=2)$ or the Bartlett's test ( $\mathrm{k} \geq 3$; $\mathrm{k}$ being the number of experimental groups) (Zar 1996). Comparison of two means from normally distributed populations without assuming equal variances was done using the "BehrensFisher problem" (Zar 1996). Testing for significant differences between coefficients of variation (CVs) was performed using the Lewontin $(\mathrm{k}=2)$ and Miller-Feltz $(\mathrm{k} \geq 3)$ equations (Zar 1996). Linear regression models were fitted using the software MINITAB 3.20 (Minitab, State College, Pennsylvania). Because larval density was found, in the present study, to have a significant effect on larval feeding rates, only replicates in which four or five larvae were recovered from the field exposure were used to compute mean postexposure feeding rates. Because no significant differences were found between feeding rates at reference sites, feeding rates at each impacted site were compared with pooled references by one-tailed U-tests (Zar 1996).

\section{Results}

\section{Feeding Quantification}

The mean $( \pm \mathrm{SD})$ feeding rate of $C$. riparius larvae fed on Tetramin for $24 \mathrm{~h}$ was $0.017( \pm 0.001 ; \mathrm{CV}=6 \%) \mathrm{mg} / \mathrm{larva} / \mathrm{h}$ and of those fed on A. franciscana nauplii for $1 \mathrm{~h}$ was 19.0 $( \pm 0.7 ; \mathrm{CV}=4 \%)$ nauplii/larva/h. Feeding rates of $C$. riparius larvae fed for $1 \mathrm{~h}$ on $A$. franciscana nauplii are shown in Figure 5 in function of the light regime and larval density. Larvae under continuous illumination ate significantly more nauplii than those in the dark $\left(t_{4.2}=60.1, p<0.001\right)$. Significant differences were also found between $C V s\left(\mathrm{~F}_{4,3}=45.6\right.$, $p<0.01$ ); results from larvae feeding under continuous light were more variable $(\mathrm{CV}=55 \%)$ than those of larvae feeding in darkness $(\mathrm{CV}=9 \%)$ (Figure 5A). The influence of larval density during the 1 -h feeding period was highly significant $\left(\mathrm{F}_{4,18}=62.0, p<10^{-9}\right)$ : one to two larvae per vial ate significantly more than four to five larvae/vial. However, no significant differences were found among the respective CVs $\left(\chi_{4}^{2}=8.1, p>0.05\right)$ (Figure 5B). A linear regression showed that larval density explained $97 \%$ of the variability in feeding rates (Figure 5B). 


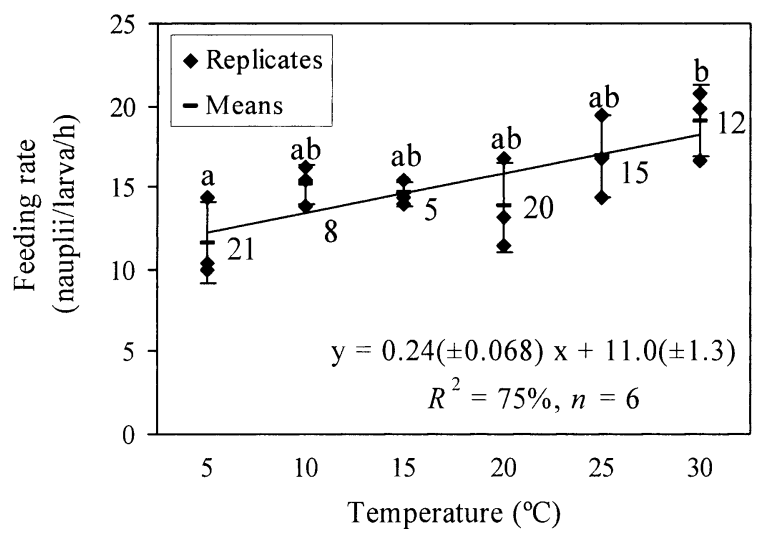

Fig. 6. Postexposure feeding rates of Chironomus riparius larvae exposed for $48 \mathrm{~h}$ at different temperatures. Error bars indicate $\pm 1 \mathrm{SD}$; numbers beside means are CVs (\%); common letters beside means identify homogeneous groups by Tukey HSD test.

\section{Influence of Exposure Conditions on Postexposure Feeding}

The influence of temperature during the 48-h exposure period on postexposure feeding rates of $C$. riparius larvae is presented in Figure 6. An ANOVA revealed significant differences in feeding among temperatures $\left(\mathrm{F}_{5,12}=4.5, p=0.015\right)$. Larvae ate more at $30^{\circ} \mathrm{C}$ than at $5^{\circ} \mathrm{C}$. No differences were found among CVs $\left(\chi^{2}{ }_{5}=4.4, p>0.05\right)$. A linear regression showed that temperature explained $75 \%$ of the variability among treatments (Figure 6). For all other environmental variables (DO, pH, salinity, hardness, substrate, humic acids, light, and food availability), no significant differences in postexposure feeding rate across treatments were observed $(p=0.090$ $0.857)$. Mean $( \pm \mathrm{SD})$ postexposure feeding rates ranged from $11.8( \pm 2.23)$ to $13.9( \pm 2.14), 10.27( \pm 1.14)$ to $14.7( \pm), 13.9$ $( \pm 3.24)$ to 15.5 ( \pm 1.33$), 14.0( \pm 2.12)$ to $17.9( \pm 1.89), 16.5$ $( \pm 2.30)$ to $20.1( \pm 1.72), 13.3( \pm 1.30)$ to $15.9( \pm 2.72), 13.8$ $( \pm 2.75)$ to $18.1( \pm 1.86)$, and $13.8( \pm 2.75)$ to $16.1( \pm 2.30)$, in the $\mathrm{DO}, \mathrm{pH}$, salinity, hardness, substrate, humic acids, light, and food availability experiments, respectively. Overall, CVs ranged from $7 \%$ to $20 \%$, except in three situations where values lower than $28 \%$ were, nevertheless, registered.

\section{In Situ Toxicity Assay}

The in situ exposure was carried out with a mean $( \pm \mathrm{SD})$ water-column temperature of $20 \pm 3^{\circ} \mathrm{C}$ at all sites. Conductivity at R1, I1, and I2 ranged from 420 to $580 \mu \mathrm{S} / \mathrm{cm}$, and at I3 from 1033 to $1132 \mu \mathrm{S} / \mathrm{cm}$, whereas conductivity at R2 was 194 $\mu \mathrm{S} / \mathrm{cm}$. Water-column $\mathrm{pH}$ was near to neutrality (6.5-7.5) except at site I3 (4.0-4.5). Water and organic matter contents of sediments were similar at all field sites (Table 1). Sediments from R2 and I2 were classified as sandy gravel, and those from R1, I1, and I3 as gravely sand; the fraction of silt and clay was small at all sites $(\leq 8 \%)$. At all sites, the most abundant metals present in the porewater were (in increasing order) $\mathrm{Fe}, \mathrm{Al}$, and Mn (Table 2). Metal concentrations at R1 were very low compared with concentrations at all others sites. The highest concentrations for almost all analyzed metals were observed at site I1, followed by site I2.
Organism recovery ranged from 60 (R2) to $87 \%$ (all other sites) (Table 3). The low recovery rate at site R2 was likely caused by difficulties when retrieving one of the assay chambers. In the other two replicates, $100 \%$ recovery was observed. Table 3 presents postexposure feeding rates for each replicate. Significant differences were found between postexposure feeding rates $\left(\mathrm{F}_{4,7}=6.96, p=0.014\right)$, but the respective Tukey HSD test revealed no differences between reference sites, although the feeding rate at R1 was $11 \%$ lower than at R2. Postexposure feeding was significantly depressed at the three impacted sites-I1, I2, and I3-relative to pooled references $\left(\mathrm{U}_{5,2}=10, p=0.05 ; \mathrm{U}_{5,3}=14, p=0.05 ; \mathrm{U}_{5,2}=10\right.$, $p=0.05$ ), by $24 \%, 15 \%$, and $34 \%$, respectively (Table 3 ).

\section{Discussion}

\section{Feeding Quantification}

Although both fish flake food and A. franciscana nauplii were demonstrated to be suitable to quantify the feeding rate of C. riparius larvae, using nauplii was easier, greatly simplifying the feeding quantification procedures and yielding more precise results. The use of Tetramin was revealed as a complex and time-consuming procedure requiring the setup of two extra treatments for calculating correction factors. Furthermore, it was possible to reduce the postexposure feeding period from 24 to $1 \mathrm{~h}$. A short postexposure feeding period is essential in order to minimize an eventual physiological recovery from the effects of the toxicant during exposure. Recovery from toxicant effects has been reported for daphnids less than $4 \mathrm{~h}$ after exposure to sublethal concentrations of copper, fluoranthene (McWilliam and Baird 2002a), and phenol (Brent and Herricks 1998).

The mean feeding rate of organisms under continuous light was significantly higher than that of organisms feeding in darkness. However, feeding under light produced feeding rates significantly more variable compared to feeding in darkness. Osborne et al. (2000) also addressed the effects of the light regime on $C$. riparius larval feeding and found that when animals were fed in darkness their guts were filled faster and more efficiently than when fed under light conditions. The latter authors concluded this might be expected as larvae are at their most vulnerable stage when feeding at the sediment surface. The high variability among replicates observed in the present study for the continuous light treatment indicates that these larvae were under stress conditions that led to a highly variable feeding behavior. In accordance with the present results, it was established that postexposure feeding rates should be quantified under dark conditions, because in this way more precise feeding rates could be achieved.

C. riparius larval density was found to be inversely proportional to larval feeding rate. Most likely, larval density influenced the food available per larva and not the feeding behavior itself. Because the food concentration per vial was similar, the probability of one larva to find a nauplium decreased with an increase in larval density. A study on density-dependent effects on the growth and development of C. riparius larvae also found that food availability is often related to the density of organisms in both natural populations 
Table 1. Sediment physicochemical parameters at each field site

\begin{tabular}{|c|c|c|c|c|c|c|}
\hline Site & Water $(\%)$ & Organic matter $(\%)$ & Silt and clay $(\%)$ & Sand $(\%)$ & Gravel $(\%)$ & Sediment classification \\
\hline R1 & 25 & 2.0 & 3 & 73 & 24 & Gravely sand \\
\hline $\mathrm{R} 2$ & 17 & 2.6 & 1 & 43 & 56 & Sandy gravel \\
\hline $\mathrm{I} 1$ & 20 & 2.6 & 8 & 53 & 39 & Gravely sand \\
\hline $\mathrm{I} 2$ & 20 & 4.0 & 2 & 47 & 52 & Sandy gravel \\
\hline $\mathrm{I} 3$ & 19 & 3.0 & 0 & 53 & 47 & Gravely sand \\
\hline
\end{tabular}

Table 2. Porewater chemical parameters at each field site.

\begin{tabular}{llllllllllll}
\hline Site & Cond & $\mathrm{pH}$ & $\mathrm{Al}$ & $\mathrm{Zn}$ & $\mathrm{Co}$ & $\mathrm{Mn}$ & $\mathrm{Cd}$ & $\mathrm{Cu}$ & $\mathrm{Fe}$ & $\mathrm{Se}$ & $\mathrm{Pb}$ \\
\hline $\mathrm{R} 1$ & 1.6 & 7.1 & 0.011 & 0.009 & $<10^{-3}$ & 0.20 & $<10^{-3}$ & $<10^{-2}$ & 0.49 & 0.001 & $<10^{-3}$ \\
$\mathrm{R} 2$ & 0.31 & 7.1 & 10 & 2.9 & 0.01 & 2.8 & 0.004 & 0.22 & 4.1 & $<10^{-3}$ & 0.46 \\
$\mathrm{I} 1$ & 1.7 & 3.1 & 65 & 9.2 & 0.6 & 43 & 0.04 & 2.0 & 11 & 0.003 & 0.16 \\
$\mathrm{I} 2$ & 3.1 & 3.6 & 15 & 3.8 & 0.3 & 31 & 0.008 & 0.81 & 75 & 0.01 & 0.16 \\
$\mathrm{I} 3$ & 1.1 & 3.6 & 14 & 2.1 & 0.08 & 3.5 & 0.01 & 0.88 & 80 & 0.001 & 0.32 \\
\hline
\end{tabular}

Note: Cond, conductivity $(\mathrm{mS} / \mathrm{cm})$. Metal concentrations are expressed as $\mathrm{mg} / \mathrm{L}$.

Table 3. Postexposure feeding rates (PEF, in nauplii/larva/h) and larvae recovery (Rec, in \%), in each of the three assay replicates, of Chironomus riparius exposed in situ for $48 \mathrm{~h}$ at the two reference (R1 and R2) and the three impacted sites (I1 to I3)

\begin{tabular}{|c|c|c|c|c|c|}
\hline \multirow{2}{*}{$\frac{\text { Site }}{\mathrm{R} 1}$} & \multicolumn{3}{|c|}{ PEF (Rec) per replicate } & \multirow{2}{*}{$\frac{\mathrm{PEF} \pm \mathrm{SD}(C V)(\mathrm{Rec})}{15.2 \pm 0.38(2)(87)}$} & \multirow[t]{2}{*}{ PEF Depress } \\
\hline & $15.5(80)$ & $14.8(80)$ & $15.2(100)$ & & \\
\hline $\mathrm{R} 2$ & $17.8(80)$ & $16.5(80)$ & $-(20)^{\mathrm{a}}$ & $17.1 \pm 0.88(5)(60)$ & \\
\hline I1 & $13.6(100)$ & $10.6(100)$ & $-(60)$ & $12.1 \pm 2.1(18)(87)$ & $24.2^{*}$ \\
\hline $\mathrm{I} 2$ & $14.0(80)$ & $11.3(80)$ & $15.2(100)$ & $13.5 \pm 2.0(15)(87)$ & $15.4^{*}$ \\
\hline I3 & $10.2(100)$ & $10.8(100)$ & $-(60)$ & $10.5 \pm 0.42(4)$ & $34.2^{*}$ \\
\hline
\end{tabular}

Notes: Only replicates in which four to five larvae were recovered were used (i.e., recovery of $80-100 \%)$. Identifies significant $(p \leq 0.05)$ postexposure feeding depression (PEF Depress, in \%) relative to pooled references.

${ }^{\text {a }}$ Sediment core was partially lost during retrieval of assay chamber.

and sediment bioassays (Ristola et al. 1999). Because similar coefficients of variation were obtained among all larval density treatments, a density of five larvae per vial was selected in this study for postexposure feeding quantifications. Such a choice allows reduction of the number of replicates required for quantifying the feeding of the five larvae/replicate at each site, and hence greatly simplifies the feeding trials. Although similar feeding conditions were provided to the larvae of the latter treatment and to those feeding in darkness in the experiment addressing the influence of light conditions, a difference of approximately twofold was found between the respective feeding rates. This apparent discrepancy in the repeatability of feeding rate measurements could be due to small differences in the size of the larvae caused by slightly different culture conditions, because the two experiments were not carried out simultaneously. However, comparable feeding rates were obtained with larvae used in all of the subsequent laboratory experiments, showing the good repeatability of the feeding quantification procedures.

\section{Influence of Exposure Conditions on Postexposure Feeding}

Temperature was the only exposure condition found to have a significant effect on postexposure feeding. As expected, because the metabolic rate of organisms is reduced with a de- crease in temperature, postexposure feeding rate was correlated with the temperature during exposure. Feeding rate was significantly lower at $5^{\circ} \mathrm{C}$ than at $30^{\circ} \mathrm{C}$. Therefore, when temperature variations larger then $20^{\circ} \mathrm{C}$ across sites would occur, which is rather unlikely, strategies to distinguish a potential toxic effect from a temperature effect would be needed (Maltby et al. 2002; Ringwood and Keppler 2002). For all other investigated exposure conditions, the absence of a significant effect on the postexposure feeding rate of $C$. riparius larvae indicates that the selected assay endpoint was not influenced by such an array of exposure variables. As a result, sites with such different (DO, pH, salinity, hardness, substrate, humic acids, light and food availability) conditions can be compared for in situ sediment toxicity evaluations with $C$. riparius larvae, unless a combination of negative conditions is present. In such a case, data on the interactions of environmental factors should be previously collected. C. riparius larvae have been shown to have a large tolerance to different sediment grain sizes and to inhabit gravel, limestone, marl, plants, and silt (Pinder 1986; Ingersoll and Nelson 1990). Pinder (1986) reported the occurrence of this species in the field at $\mathrm{pH}$ between 5 and 9 , and at DO concentrations as low as $1 \mathrm{mg} / \mathrm{L}$. The present study also shows that freshwaters and brackish waters up to $6.0 \mathrm{~g} / \mathrm{L}$ salinity can be directly compared for postexposure feeding rates. Although the transfer from one salinity level to another was found to cause a physiological 
effect, which increased the variability in the uptake of zinc by C. riparius fourth-instar larvae (Bervoets et al. 1996), such transferring did not influence postexposure feeding within the salinity range evaluated here $(0.0-6.0 \mathrm{~g} / \mathrm{L})$. However, caution should be taken when working at higher salinities. In fact, mortality of $C$. riparius fourth-instar larvae was $100 \%$ when exposed at a salinity as high as $12 \mathrm{~g} / \mathrm{L}$ (I. Cativa, personal observation). Postexposure feeding was not influenced by the light conditions prevailing during the 48-h exposure period; postexposure feeding rates of larvae exposed under a light regime and in darkness were comparable.

\section{In Situ Toxicity Assay}

The developed chamber and protocols were suitable for exposing $C$. riparius larvae in situ in a variety of aquatic systems, i.e., from lentic to lotic and in sediments with a wide sediment particle size range. The chamber and auxiliary structures were easily constructed with inexpensive materials, and deployed at the field sites without difficulties. The advantages of using assay chambers made of transparent material for better simulating the natural light regime have been already pointed out (Castro et al. 2003); it allows exposure under natural light conditions, making possible the integration of potential light effects on organism performance as well as the assessment of photoactivated toxicants (Monson et al. 1995; Ireland et al. 1996). According to the proposed protocol, disturbance of the sediment after deployment can be minimized by first allowing the establishment of an (at least partial) equilibrium between the sediment porewater inside and outside of the chambers, then deploying organisms $2 \mathrm{~m}$ away from the chambers. It was also shown that this new chamber can be successfully used in soft sediments because the leveling structures prevented the system from sinking. Furthermore, chambers could be successfully employed in lentic as well as lotic systems. The occurrence of indigenous organisms inside in situ chambers raises concerns about predation on test organisms and misidentification due to structural similarities between test and indigenous organisms (Chappie and Burton 1997). In this study, the use of a 200- $\mu \mathrm{m}$ nylon mesh for assay chamber construction was adequate to avoid problems with indigenous organisms at all study sites, although the need to use chambers with an open end does not permit eradication of this possibility. As pointed out by Crane et al. (2000), marking the test organisms prior to deployment would be a solution to this problem for in situ assays carried out at sites where natural populations occur. A recovery rate of $87 \%$ was observed at all except one site (R2), but this was likely due to problems retrieving one assay chamber. A possible solution to such problems, to be considered for in situ assays in general, would be the deployment of extra assay chambers, although only the first three successfully retrieved chambers (sediment remaining in the tube) should be used for assay endpoint estimation.

The $11 \%$ difference in postexposure feeding found between the two reference sites, though not significant, highlighted the difficulty inherent to in situ bioassays of selecting appropriate uncontaminated reference sites with characteristics that do not influence assay organism performance (Chappie and Burton
2000). Sediment and porewater physicochemical characteristics registered at the reference sites were not similar. Site R1 had higher water-column and porewater conductivities than site R2, which could be indicative of other habitat quality parameters not measured. Moreover, sediment at R1 was observed to have many plant roots, which may have influenced organism performance. For practical reasons, a larval density of five individuals per vial had been initially selected for postexposure feeding quantifications. However, results from the in situ assay indicated that the need for replicate rejection when larval density levels of replicates within a treatment are not directly comparable for feeding rate quantification may sometimes be ineffective. Such a procedure can reduce the power of the assay to discriminate across-sites postexposure feeding depression. It is well known that the power of a test to discriminate differences among treatments is reduced by increases in within-treatment variability, which is in turn highly dependent on the number of replicates (Burton et al. 1996; ASTM 2002a). Therefore, individual postexposure feeding rate quantifications, even though more laborious, should be considered. In this way, feeding rates of all larvae recovered from assay chambers can be quantified and directly compared, increasing the power of the assay.

Although determination of the prime causes for a toxic effect on $C$. riparius larvae was not a primary objective of this study, based on the measured water and sediment quality parameters an attempt was made to infer the possible factors determining postexposure feeding depression at the impacted sites. Unexpectedly, the highest metal concentrations were not found at the sites with the highest feeding depression. However, metal pollution is known to occur generally as a mixture of different metals that interact with each other, and toxicity of a mixture is not the sum of the toxicity of the parts (Gerhardt 1993). Furthermore, total metal analyses are not indicative of the fraction of metals available to organisms, because bioavailability depends on the metal, the form of the metal, and largely on water-quality parameters such as $\mathrm{pH}$, hardness, and inorganic and organic ligands (Gerhardt 1993). In particular, sediments contaminated with acid mine drainage are known to have complex chemical and physical properties, and the factors potentially contributing to toxicity are quite numerous (Lopes et al. 1999a; Pereira et al. 2000; Moreira-Santos et al. 2004). The high postexposure feeding depression observed at site I3 may be explained by the low $\mathrm{pH}$ in both water-column (4.0-4.5) and porewater (3.6), a combination not found at sites I1 and I2. The role of $\mathrm{pH}$ on metal toxicity has been studied. In addition to the direct toxic effects due to hydrogen ions (Kelly 1991; Gerhardt 1993), the availability of the free metal ions increases at low $\mathrm{pH}$, and in general there is an increase in metal uptake (Gerhardt 1993).

In conclusion, the in situ sublethal assay proposed here has, contrary to most in situ sublethal assays, the additional advantage of reducing exposure to a period as short as $48 \mathrm{~h}$, rendering it a rapid and cost-effective assessment tool appropriate for routine use. It can be used in both lentic and lotic systems and in soft sediments. Moreover, the laboratory evaluation of environmental exposure conditions on $C$. riparius larvae postexposure feeding showed that this in situ assay can be used under a relatively wide range of environmental conditions not (per se) detrimental to organism performance. 
Therefore, the proposed short-term in situ assay is a potentially useful tool to routinely assess sediment sublethal toxicity.

Acknowledgments. This work was partially funded by the European Commission (TARGET project, ref. EVK1-1999-00018) and the Portuguese FCT (PIN project, ref. POCTI/CEC/34891/99). The authors would like to thank Sofia Andrade for field assistance and André Moutinho for help with the use of Corel Draw 10.0 software.

\section{References}

American Public Health Association Standard methods for the examination of water and wastewater, 19th ed. American Public Health Association, Washington, DC

American Society for Testing and Materials (2002a) Test method for measuring the toxicity of sediment-associated contaminants with freshwater invertebrates. In: Annual Book of American Society for Testing and Materials Standards, Vol 11.05, E 1706-00e2. American Society for Testing and Materials, Philadelphia, Pennsylvania

American Society for Testing and Materials (2002b) Standard guide for conducting acute toxicity tests on test materials with fishes, macroinvertebrates, and amphibians. In: Annual Book of American Society for Testing and Materials Standards, Vol 11.05, E 729-96. American Society for Testing and Materials Philadelphia, Pennsylvania

Begon M, Harper JL, Townsend CR (1996) Ecology-individuals, populations and communities Blackwell Science, Oxford

Bervoets L, Blust R, Verheyen R (1996) Uptake of zinc by the midge larvae Chironomus riparius at different salinities: role of speciation, acclimation, and calcium. Environ Toxicol Chem 15:14231428

Brent RN, Herricks EE (1998) Postexposure effects of brief cadmium, zinc, and phenol exposures on freshwater organisms. Environ Toxicol Chem 17:2091-2099

Buchanan JB, Kain JM (1971) Measurement of the physical and chemical environment. In: Holme NA, McIntyre AD, (eds). Methods for the study of marine benthos-IBP handbook, 16. Blackwell Scientific Publications, Oxford, pp 30-58

Burton GA Jr, Arnold WR, Ausley LW, Black JA, DeGraeve GM, Fulk FA, Heltshe JF, Peltier WH, Pletl JJ, Rodgers JH Jr (1996) Effluent toxicity test variability: discussion synopsis. In: Grothe DR, Dickson KL, Reed-Judkins, (eds). Whole effluent toxicity testing: an evaluation of methods and prediction of receiving system impacts. Society of Environmental Contamination and Contamination Press, Pensacola, Florida, pp 131-156

Cairns J Jr., Cherry DS (1993) Freshwater multi-species test systems. In: Calow P, (eds). Handbook of ecotoxicology, Vol 1. Blackwell Scientific Publications, Oxford, pp 101-116

Carr RS, Williams JW, Fragata CTB (1989) Development and validation of a novel marine sediment pore-water toxicity test with the polychaete Dinophilus gyrocilliatus. Environ Toxicol Chem 8:533-543

Castro BB, Guilhermino L, Ribeiro R (2003) In situ chambers and procedures for assessment of sediment toxicity with Chironomus riparius. Environ Pollut 125:325-335

Castro BB, Sobral O, Guilhermino L, Ribeiro R (2004) An in situ bioassay integrating individual and biochemical responses using small fish species. Ecotoxicology 13:667-681

Chappie DJ, Burton GA Jr (1997) Optimization of in situ bioassays with Hyalella azteca and Chironomus tentans. Environ Toxicol Chem 16:559-564
Chappie DJ, Burton GA Jr (2000) Applications of aquatic and sediment toxicity testing in situ. Soil Sed Contam 9:219-245

Crane M, Higman M, Olsen T, Simpson P, Callaghan A, Fisher T, Rheir R (2000) An in situ system for exposing aquatic invertebrates to contaminated sediments. Environ Toxicol Chem 19:2715-2719

Gerhardt A (1993) Review of impact of heavy metals on stream invertebrates with special emphasis on acid conditions. Water Air Soil Pollut 66:289-314

Guillard RRL (1983) Culture of phytoplankton for feeding marine invertebrates. In: Berg J Jr, (ed). Culture of marine invertebrates. Hutchinson-Ross, Pennsylvania, pp 108-132

Ingersoll CG, Nelson MK (1990) Testing sediment toxicity with Hyalella azteca (Amphipoda) and Chironomus riparius (Diptera). In: Landis WG, Schalie WHvan der, (eds). Aquatic toxicology and risk assessment: thirteenth volume American Society for Testing and Materials STP 1096. American Society for Testing and Materials, Philadelphia, Pennsylvania, pp 93-109

Ingersoll CG, Ankley GT, Benoit DA, Brunson EL, Burton GA, Dwyer FJ, Hoke RA, Landrum PF (1995) Toxicity and bioaccumulation of sediment-associated contaminants using freshwater invertebrates: a review of methods and applications. Environ Toxicol Chem 14:1885-1894

Ireland DS, Burton GA Jr, Hess GG (1996) In situ toxicity evaluations of turbidity and photoinduction of polycyclic aromatic hydrocarbons. Environ Toxicol Chem 15:574-581

Juchelka CM, Snell TW (1994) Rapid toxicity assessment using rotifer ingestion rate. Arch Environ Contam Toxicol 26:549-554

Juchelka CM, Snell TW (1995) Rapid toxicity assessment using ingestion rate of cladocerans and ciliates. Arch Environ Contam Toxicol 28:508-512

Kelly M (1991) Mining and the freshwater environment Elsevier Science Publishers, Barking, Essex

Larrain A, Riveros A, Bay-Schmith E, Roa R (1997) Evaluation of three larval instars of the midge Chironomus petiolatus as bioassay tools using a computationally intensive statistical algorithm. Arch Environ Contam Toxicol 33:407-414

Little EE, DeLonay AJ (1996) Measures of fish behavior as indicators of sublethal toxicosis during standard toxicity tests. In: La Point TW, Price FT, Little EE, (eds). Environmental toxicology and risk assessment, vol 4. STP 1262. American Society for Testing and Materials, Philadelphia, Pennsylvania, pp 216-233

Lopes I, Gonçalves F, Soares AMVM, Ribeiro R (1999a) Discriminating the ecotoxicity due to metals and to low $\mathrm{pH}$ in acid mine drainage. Ecotoxicol Environ Saf 44:207-214

Lopes I, Gonçalves F, Soares AMVM, Ribeiro R (1999b) Ecotoxicological tools in the remediation of acid mine drainage. Toxicol Environ Chem 70:441-460

Maltby L (1994) Stress, shredders and streams: using Gammarus energetics to assess water quality. In: Sutcliffe DW, (eds). Water quality and stress indicators in marine and freshwater systems: linking levels of organisation. Freshwater Biological Association, Ambleside, Cumbria, pp 98-110

Maltby L, Clayton SA, Wood RM, McLoughlin N (2002) Evaluation of the Gamarus pulex in situ feeding assay as a biomonitor of water quality: robustness, responsiveness, and relevance. Environ Toxicol Chem 21:361-368

McWilliam RA, Baird DJ (2002a) Postexposure feeding depression: a new toxicity endpoint for use in laboratory studies with Daphnia magna. Environ Toxicol Chem 21:1198-1205

McWilliam RA, Baird DJ (2002b) Application of postexposure feeding depression bioassays with Daphnia magna for assessment of toxic effluents in rivers. Environ Toxicol Chem 21:1462-1468

Monson PD, Ankley GT, Kosian PA (1995) Phototoxic response of Lumbricus variegates to sediments contaminated by polycyclic aromatic hydrocarbons. Environ Toxicol Chem 14:891-894 
Moreira-Santos M, Soares AMVM, Ribeiro R (2004) A microalgal growth assay for routine in situ environmental assessments in freshwater systems. Environ Toxicol Chem 23: $1549-1560$

Organization for Economic Cooperation and Development (2001) Sediment-water chironomid toxicity test using spiked waterdraft document. Organization for Economic Cooperation and Development guidelines for the testing of chemicals - proposal for a new guideline 219. Organization for Economic Cooperation and Development, Paris

Osborne S, Hurrell S, Simkiss K, Leidi A (2000) Factors influencing the distribution and feeding of the larvae of Chironomus riparius. Entomol Exp Appl 94:67-73

Pereira AMM, Soares AMVM, Gonçalves F, Ribeiro R (1999) Test chambers and test procedures for in situ toxicity testing with zooplankton. Environ Contam Toxicol 18:1956-1964

Pereira AMM, Soares AMVM, Gonçalves F, Ribeiro R (2000) Watercolumn, sediment and in situ chronic bioassays with cladocerans. Ecotoxicol Environ Saf 47:27-38

Pereira EG, Moura I, Costa JR, Mahony JD, Thomann RV (1995) The S. Domingos mine:a-study of heavy metal contamination in the water column and sediments of the Chança River basin by discharge from an ancient cupriferous pyrite mine (Portugal) Mar Freshwat Res 46:145-151

Pinder LCV (1986) Biology of freshwater chironomidae. Ann Rev Entomol 31:1-23

Postma JF, Van Kleunen A, Admiraal W (1995) Alterations in lifehistory traits of Chironomus riparius (Diptera) obtained from metal contaminated rivers. Arch Environ Contam Toxicol 29:469-475

Ribeiro R, Kelly LA, Gonçalves F, Burton GA, Soares AMVM (1999) New artificial sediment for Chironomus riparius toxicity testing. Bull Environ Contam Toxicol 63:691-697
Ringwood AH, Keppler CJ (2002) Comparative in situ and laboratory bioassays with juvenile Mercenaria mercenaria. Environ Toxicol Chem 21:1651-1657

Ristola T, Pellinen J, Ruokolainen M, Kostamo A, Kukkonen JVK (1999) Effect of sediment type, feeding level, and larvae density on growth and development of a midge (Chironomus riparius). Environ Toxicol Chem 18:756-764

Sibley PK, Benoit DA, Ankley GT (1997) The significance of growth in Chironomus tentans sediment toxicity tests: relationship to reproduction and demographic endpoints. Environ Toxicol Chem 16:336-345

Stuijfzand SC, Drenth MH, Kraak MHS (1998) Bioassays using the midge Chironomus riparius and the zebra mussel Dreissena polymorpha for evaluation of river water quality. Arch Environ Contam Toxicol 34:357-363

Timmermans KR, Peeters W, Tonkes M (1992) Cadmium, zinc, lead and copper in Chiromonus riparius (Meigen) larvae (Diptera, Chironomidae): uptake and effects. Hydrobiologia 241:119-134

Tucker KA, Burton GA Jr (1999) Assessment of nonpoint-source runoff in a stream using in situ and laboratory approaches. Environ Toxicol Chem 18:2797-2803

United States Environmental Protection Agency (1989) Short-term methods for estimating the chronic toxicity of effluents and receiving waters to freshwater organisms. United States Environmental Protection Agency, EPA/600/4-89-001, Cincinnati, Ohio

United States Environmental Protection Agency (2000) Methods for measuring the toxicity and bioaccumulation of sediment-associated contaminants with freshwater invertebrates, 2nd edition. United States Environmental Protection Agency, EPA/600/R-99/ 064, Washington, DC

Zar JH (1996) Biostatistical analysis Prentice Hal, Upper Saddle River, New Jersey 